\title{
HISTOLOGY AND HISTOCHEMISTRY OF THE VENOM APPARATUS OF THE BLACK SCORPION Androctonus crassicauda (OLIVIER, 1807) (SCORPIONES: BUTHIDAE)
}

\section{JARRAR BM (1), AL-ROWAILY MA (1)}

(1) Department of Clinical Laboratory Sciences, College of Applied Medical Sciences, Al-Jouf University, Skaka, Al-Jouf, Saudi Arabia.

ABSTRACT: The venom apparatus of the black scorpion Androctonus crassicauda has been characterized histologically and histochemically in the present study. The results showed that this apparatus consists of paired venom glands, each of which initially presents its own canal and posteriorily both fuse into a single common one. Each gland is covered by a sheath of striated muscle and is lined with extensively folded secretory epithelium (formed of non-secretory and secretory venom-producing cells). The outcomes also revealed that the venom-producing cells of both glands produce neutral mucosubstances, sialomucins, sulfomucins and proteins, but are devoid of glycogen. Cysteine, tyrosine, tryptophan and arginine were also detected along with activities of acid and alkaline phosphatases, mitochondrial adenosine triphosphatase, aminopeptidase, cholinesterase and non-specific esterases. Structure and secretion of scorpion venom glands are discussed within the context of the present results.

KEY WORDS: Androctonus, scorpion, venom apparatus, histochemistry, phosphatases, esterases, peptidases.

CONFLICTS OF INTEREST: There is no conflict.

CORRESPONDENCE TO:

BASHIR M. JARRAR, Department of Clinical Laboratory Sciences, College of Applied Medical Sciences, Al-Jouf University, PO Box 2014, Skaka, Al-Jouf, Saudi Arabia. Fax: 009664 6257328, mobile: 00966503229854. Email: bashirjarrar@yahoo.com. 
B. M. Jarrar and M. A. Al-Rowaily HISTOLOGY AND HISTOCHEMISTRY OF THE VENOM APPARATUS OF THE BLACK SCORPION Androctonus crassicauda (OLIVIER, 1807) (SCORPIONES: BUTHIDAE). J. Venom. Anim. Toxins incl. Trop. Dis., 2008, 14, 3, p. 515

\section{INTRODUCTION}

Androctonus crassicauda has been reported to be present in various localities in Saudi Arabia and in other parts of the Arabian Peninsula (2, 3, 12, 15, 24, 35). This species is considered one of the most dangerous scorpions in Saudi Arabia and neighboring countries $(1,2-7,12,28,30)$ and its stings may account for mortalities $(8,10,14,16)$.

Although the morphology of scorpion venom apparatus has been described by many investigators, few studies have focused on its histochemistry $(19,20,25,27,34)$. In this context, the present study was performed to characterize the histology and histochemistry of Androctonus crassicauda venom glands.

\section{MATERIALS AND METHODS}

The venom apparatus of 16 Androctonus crassicauda adult males and females, captured from the central, northeast and Al-Jouf provinces of Saudi Arabia, were utilized. The telson was removed from each scorpion and quickly immersed for five days in one of the following fixatives: $10 \%$ neutral buffered formalin ( $\mathrm{pH} 7.4$ ) with $2 \%$ calcium acetate (eight telsons); Boui's fluid (four telsons) and Gendre's fluid (four telsons). The cuticles of all fixed telsons were removed with a sharp blade, by scratching, then thoroughly washed in running water, dehydrated, cleared, impregnated and embedded in paraffin wax, sectioned at 4 to $5 \mu \mathrm{m}$ thickness and stained with hematoxylin-eosin and Masson trichrome stains for histological examination. Eight other telsons were removed from adult scorpions and their cuticles were detached from the intact telson muscular coat after tranquilization with liquid nitrogen for subsequent preparation of fresh, unfixed frozen sections. Paraffin and frozen sections were then to detect mucosubstances, proteins, amino acids and enzymes activities utilized in the following histochemical reactions.

\section{Neutral Mucosubstances}

- Techniques: periodic acid-Schiff (PAS), PAS after diastase digestion, PAS after $\alpha$-amylase digestion and Best's carmine (32).

Neutral mucosubstances are PAS-positive, diastase-resistant, as well as unstainable by cationic dyes. Acetylation produces derivatives of primary and secondary amines 
B. M. Jarrar and M. A. Al-Rowaily HISTOLOGY AND HISTOCHEMISTRY OF THE VENOM APPARATUS OF THE BLACK SCORPION Androctonus crassicauda (OLIVIER, 1807) (SCORPIONES: BUTHIDAE). J. Venom. Anim. Toxins incl. Trop. Dis., 2008, 14, 3, p. 516

that prevent 1, 2 glycol groups from reacting with PAS, indicating the presence of neutral mucosubstances or sialic acid, separately or simultaneously.

\section{Acid Mucosubstances}

- $\quad$ Techniques: alcian blue $(\mathrm{AB})$ at $\mathrm{pH} 2.5$ and 1.0 (13).

Alcian blue is generally considered specific for identifying acid mucosubstances whereas alcianophilia at $\mathrm{pH} 2.5$ and 1.0 is specific for sialomucins and sulformucins, respectively (32).

\section{Distinction between Acidic and Neutral Mucosubstances}

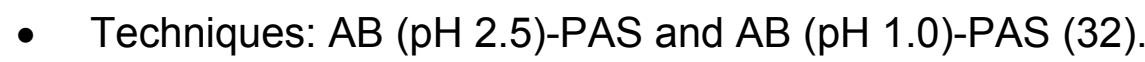

\section{Distinction between Sulfomucins and Sialomucins}

- Techniques: aldehyde fuchsin (AF) and aldehyde fuchsin-alcian blue at $\mathrm{pH} 2.5$, strong $\left(60^{\circ} \mathrm{C}, 4 \mathrm{~h}\right)$ methylation-saponification- $\mathrm{AB}, \mathrm{pH} 2.5$; acid hydrolysis $(0.1 \mathrm{~N}$ $\mathrm{HCl}, 60^{\circ} \mathrm{C}, 4 \mathrm{~h}$ )-AB ( $\left.\mathrm{pH} 2.5\right)$; toluidine blue (TB) buffered at $\mathrm{pH} 1.7$ and 3.4 and critical electrolyte concentration (CEC) technique for quenching of alcianophilia at $\mathrm{pH} 5.6$ in the presence of gradual concentration of $\mathrm{Mg}^{++}(32)$.

In the combined aldehyde fuchsin-alcian blue sequential techniques, sulfomucins stain bluish purple and sialomucins, blue $(9,22)$. Methylation blocks subsequential staining of simple mucosubstances by esterification of carboxyl groups and desulfation of complex sulfated mucosubstances. Subsequent treatment with potassium hydroxide (saponification) after methylation restores the staining of carboxyl groups (13). The mucosubstances that are stained in $0.1 \mathrm{M} \mathrm{MgCl}_{2}$ in the CEC reaction, but not in $0.2 \mathrm{M} \mathrm{MgCl}_{2}$ are believed to contain carboxyl groups and no sulfate. Sulfated mucosubstances, on the other hand, stain strongly and selectively at $0.2 \mathrm{M} \mathrm{Mg}^{++}$, but lose their alcianophilia to different degrees with increasing $\mathrm{MgCl}_{2}$ concentration (32). 
B. M. Jarrar and M. A. Al-Rowaily HISTOLOGY AND HISTOCHEMISTRY OF THE VENOM APPARATUS OF THE BLACK SCORPION Androctonus crassicauda (OLIVIER, 1807) (SCORPIONES: BUTHIDAE). J. Venom. Anim. Toxins incl. Trop. Dis., 2008, 14, 3, p. 517

\section{Enzyme Digestion Tests}

- Techniques: diastase-PAS; neuraminidase (sialidase, Vibrio cholerae, type V)$\mathrm{AB}$ at $\mathrm{pH}$ 2.5; hyaluronidase (testicular)-AB $\mathrm{pH} 2.5$, neuraminidase- $\mathrm{TB}(\mathrm{pH} 3.7)$ and hyaluronidase-TB pH 2.0 (32).

Control sections were incubated in the buffer solutions without enzymes. Sialomucins could be identified at $\mathrm{pH} 2.5$ by the presence of alcianophilia, which is partially lost following acid hydrolysis and completely abolished after neuraminidase digestion; however, this property does not affect the staining of sulfated mucosubstances. A loss of alcianophilia after hyaluronidase digestion is due to the removal of hyaluronic acid and chondroitin sulfates.

\section{Proteins}

- Techniques: mercuric bromophenol blue; ninhydrin-Schiff and chloramine TSchiff (32).

\section{Amino Acids}

- Techniques: the p-DMAB-nitrate method for tryptophan; the Sakaguchi dichloronaphthol reaction for arginine; Millon's reaction (Baker modification) for tyrosine and the ferric ferrocyanide method for cysteine (32).

\section{Enzyme Activities}

Unfixed fresh frozen sections were used for the histochemical characterization of phosphatases according to the following methods: the calcium cobalt method for alkaline phosphatase (23); the lead nitrate method for acid phosphatase (9); the Ogawa and Mayahara method for mitochondrial adenosine triphosphatase (31); the a-naphthol acetate method for non-specific esterases (31); McCabe and Chayen method for aminopeptidase and the acetylthiocholine method for cholinesterases (23). The specificity of each reaction was controlled by incubating a parallel set of sections in the medium without substrate. 
B. M. Jarrar and M. A. Al-Rowaily HISTOLOGY AND HISTOCHEMISTRY OF THE VENOM APPARATUS OF THE BLACK SCORPION Androctonus crassicauda (OLIVIER, 1807) (SCORPIONES: BUTHIDAE). J. Venom. Anim. Toxins incl. Trop. Dis., 2008, 14, 3, p. 518

\section{RESULTS}

\section{Morphology and Histology}

The venom apparatus of Androctonus crassicauda presents similar completely separated bilateral venom glands covered by cuticle. Each gland has its own canal that fuses into a single common canal in the acleus, the tapered curved end of the telson. The glandular epithelium is folded and consists of a mass of secretory epithelium, covered by a sheath of striated muscles (Figure 1A). The glandular epithelium consists of venom-producing cells and non-secretory supporting cells. The venom-producing cells are apocrine, high columnar in shape, filled with coarse granules in the apical portion and present basally situated small nuclei. The supporting cells are subcuboidal in shape, located between the venom-producing cells and the underlying basement membrane (Figure 1B). The common canal of Androctonus crassicauda venom apparatus lacks musculature and is lined with a chitinous internal layer, followed by a non-excretory simple cuboidal epithelium. The extruded venom, within the gland lumen, and within the apical cytoplasm of the venom-producing cells, contains fine and coarse granules, with discrete morphologies, that showed variable coloration patterns when using the same histological stain.

\section{Carbohydrates Histochemistry}

As shown in Table 1, the venom-producing cells reacted positively to PAS, but responded negatively to Best's carmine stain (Figure 1C). This reactivity withstood $\alpha$ amylase digestion, but was completely blocked by both phenylhydrazine and acetylation, and partly restored by deacetylation-PAS sequential techniques. These cells showed alcianophilia at both pH 2.5 (Figure 1D) and 1.0, and this property was not affected by neuraminidase or hyaluronidase digestion, but was partly inhibited by acid hydrolysis, completely blocked by strong methylation, and restored partially with methylation-saponification sequential techniques. The glandular epithelium showed strong reaction with the CEC at $0.2 \mathrm{M}$ and $0.3 \mathrm{M} \mathrm{Mg}^{++}$and a feeble one at $0.4 \mathrm{M}$ $\mathrm{Mg}^{++}$. The venom granules in both the lumen and the apical part of the venomproducing cells were stained positively by aldehyde fuchsin dye, colored purple by $\mathrm{AB}(\mathrm{pH}$ 2.5)-PAS (Figure 1E) and showed metachromatic reaction with TB at both $\mathrm{pH}$ 1.7 and 3.4 (Figure 1F). 
B. M. Jarrar and M. A. Al-Rowaily HISTOLOGY AND HISTOCHEMISTRY OF THE VENOM APPARATUS OF THE BLACK SCORPION Androctonus crassicauda (OLIVIER, 1807) (SCORPIONES: BUTHIDAE). J. Venom. Anim. Toxins incl. Trop. Dis., 2008, 14, 3, p. 519

Table 1. Histochemical reactions revealed by the glandular epithelium in Androctonus crassicauda venom apparatus

\begin{tabular}{l|c}
\hline \multicolumn{1}{|c|}{ Histochemical method ${ }^{*}$} & Result \\
\hline Periodic acid-Schiff (PAS) &,$++ \mathrm{P}$ \\
\hline Diastase digestion-PAS & $\mathrm{Nb}$ \\
\hline Best's carmine & - \\
\hline Phenylhydrazine-PAS & $\mathrm{Cb}$ \\
\hline Acetylation-PAS & $\mathrm{Cb}$ \\
\hline Acetylation-deacetylation-PAS &,$+ \mathrm{P}$ \\
\hline Alcian blue (pH 1.0) & + \\
\hline Alcian blue (pH 2.5) & ++ \\
\hline Alcian blue (pH 2.5)-PAS &,$++ \mathrm{Bp}$ \\
\hline Aldehyde fuchsin &,$+ \mathrm{P}$ \\
\hline Aldehyde fuchsin-alcian blue (pH 1.0) &,$+ \mathrm{Bp}$ \\
\hline Aldehyde fuchsin-alcian blue (pH 2.5) &,$+ \mathrm{Bp}$ \\
\hline Acid hydrolysis-alcian blue (pH 2.5) &,$+ \mathrm{B}$ \\
\hline Strong methylation-alcian blue (pH 2.5) &,$- \mathrm{Cb}$ \\
\hline Strong methylation-saponification-alcian blue (pH 2.5) &,$+ \mathrm{B}$ \\
\hline Critical electrolyte concentration (AB, 0.1 M) & ++ \\
\hline Critical electrolyte concentration (AB, 0.2 M) & + \pm \\
\hline Critical electrolyte concentration (AB, 0.4 M) & + \\
\hline Neuraminidase-AB (pH 2.5) &,$+ \mathrm{Nb}$ \\
\hline Hyaluronidase-AB (pH 2.5) &,$+ \mathrm{Nb}$ \\
\hline Toluidine blue (pH 1.7) & + \\
\hline Toluidine blue (pH 3.4) & + \\
\hline Ninhydrin-Schiff & + \\
\hline Hg-bromophenol blue & + \\
\hline Chloramine T-Schiff & + \\
\hline Ferric ferrocyanide method & + \\
\hline p-DMAB-nitrate method & + \\
\hline Sakaguchi reaction & + \\
\hline Millon's reaction & + \\
\hline
\end{tabular}


B. M. Jarrar and M. A. Al-Rowaily HISTOLOGY AND HISTOCHEMISTRY OF THE VENOM APPARATUS OF THE BLACK SCORPION Androctonus crassicauda (OLIVIER, 1807) (SCORPIONES: BUTHIDAE). J. Venom. Anim. Toxins incl. Trop. Dis., 2008, 14, 3, p. 520

\begin{tabular}{l|c}
\hline Alkaline phosphatase activity & \pm \\
\hline Acid phosphatase activity & + \\
\hline Mitochondrial ATPase activity & + \\
\hline Non-specific esterase activity & + \\
\hline Aminopeptidase activity & ++ \\
\hline Cholinesterase activity & + \\
\hline Lipase & - \\
\hline
\end{tabular}

*Histochemical reactions intensity: - (negative); \pm (feeble); + (moderate); ++ (strong); M (metachromasia - indication of acidic groups).

Degree of histochemical reaction blockade: $\mathrm{Cb}$ (complete blockade); $\mathrm{Pb}$ (partial blockade); $\mathrm{Nb}$ (no blockade). Colors: B (blue); Bp (bluish purple); P (pink).

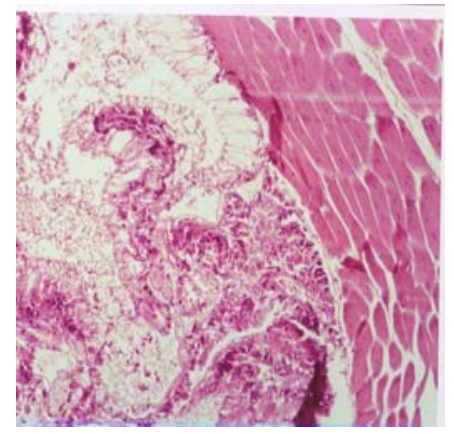

(A)

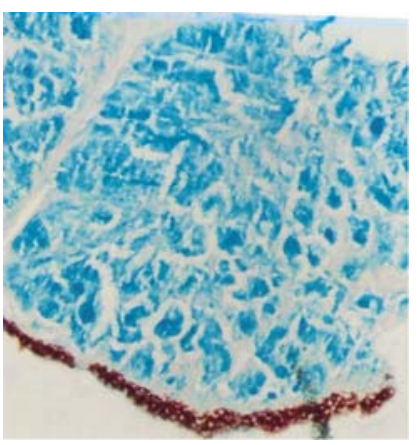

(D)

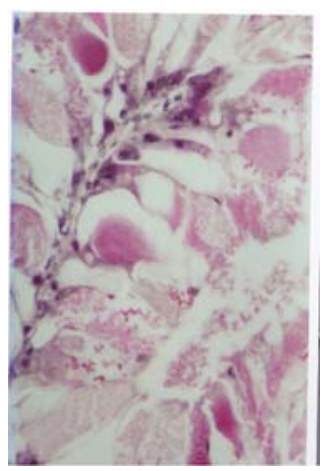

(B)

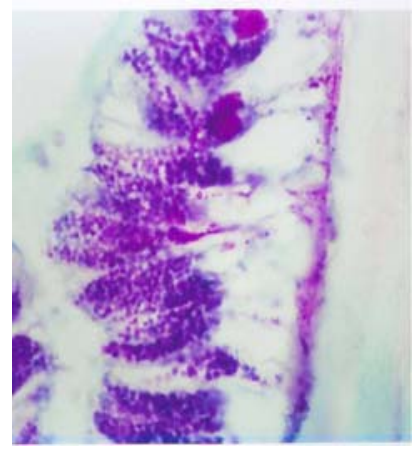

$(\mathrm{E})$

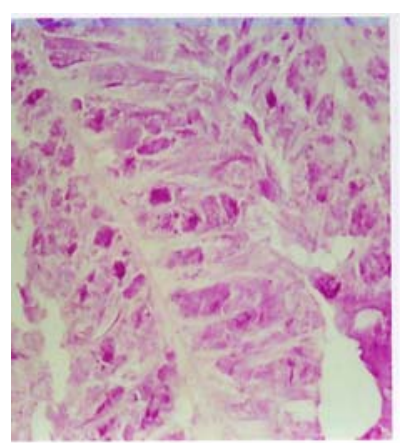

(C)

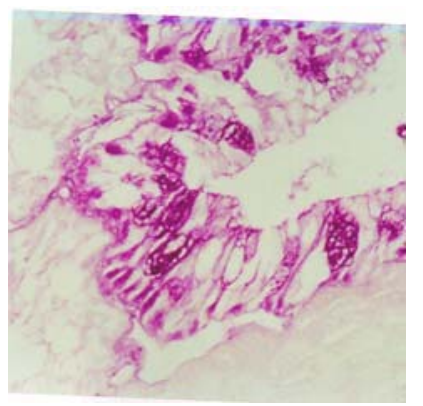

$(\mathrm{F})$

Figure 1. Cross-section of $A$. crassicauda venom glands stained with: (A) hematoxylin-eosin, secretory epithelium covered by striated muscle; (B) hematoxylineosin, with venom-producing cells and non-secretory supporting cells; (C) periodic acid-Schiff stain; (D) alcian blue ( $\mathrm{pH} 2.5)$ stain; (E) periodic acid-Schiff-alcian blue $(\mathrm{pH} 2.5)$ stain; $(\mathbf{F})$ toluidine blue $(\mathrm{pH} 3.4)$. 
B. M. Jarrar and M. A. Al-Rowaily HISTOLOGY AND HISTOCHEMISTRY OF THE VENOM APPARATUS OF THE BLACK SCORPION Androctonus crassicauda (OLIVIER, 1807) (SCORPIONES: BUTHIDAE). J. Venom. Anim. Toxins incl. Trop. Dis., 2008, 14, 3, p. 521

\section{Protein Histochemistry}

The venom-producing cells reacted positively to ninhydrin-Schiff, chloramine-T Schiff and mercuric bromophenol blue techniques (Figure 2A).

\section{Amino Acid Histochemistry}

As shown in Table 1, positive histochemical reactions for cysteine, tyrosine, tryptophan and arginine were seen in both venom-producing cells and luminalreleased venom granules (Figure 2).

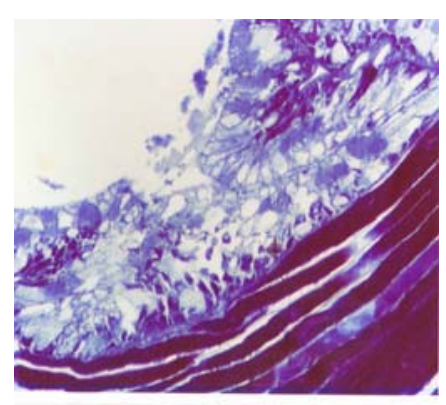

(A)

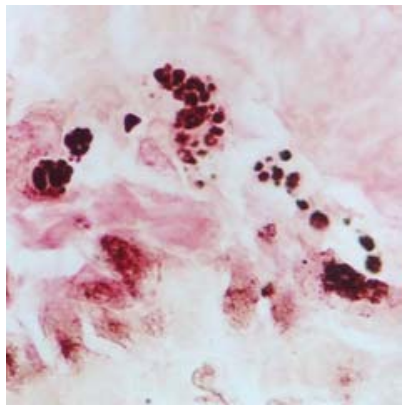

(C)

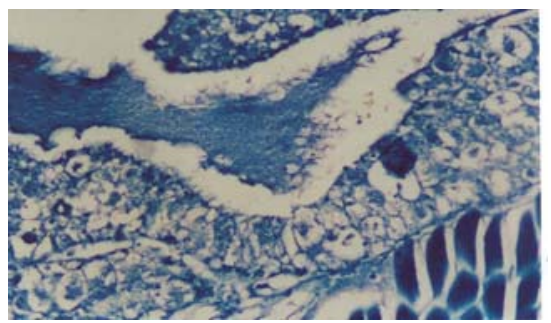

(B)

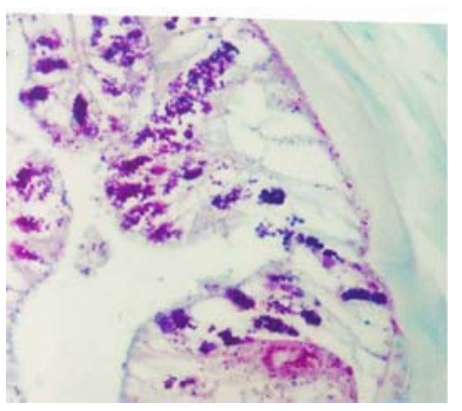

(D)

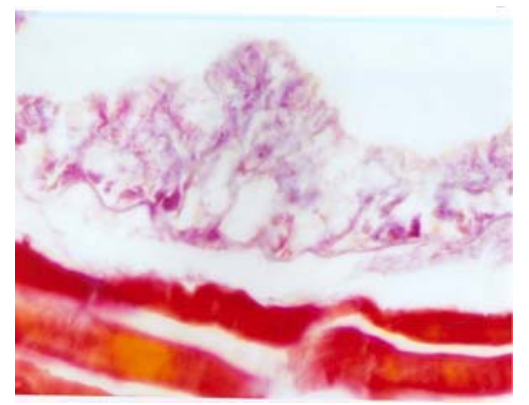

$(\mathrm{E})$

Figure 2. Cross-section of $A$. crassicauda venom glands showing: (A) proteins; (B) cysteine; (C) tyrosine; (D) tryptophan; (E) arginine. 
B. M. Jarrar and M. A. Al-Rowaily HISTOLOGY AND HISTOCHEMISTRY OF THE VENOM APPARATUS OF THE BLACK SCORPION Androctonus crassicauda (OLIVIER, 1807) (SCORPIONES: BUTHIDAE). J. Venom. Anim. Toxins incl. Trop. Dis., 2008, 14, 3, p. 522

\section{Enzyme Histochemistry}

Considerable activity of amino peptidase (Figure $3 \mathrm{~A}$ ) was detected in both venomproducing cells and luminal-released venom granules. Acid phosphatase, mitochondrial ATPase, non-specific esterases and cholinesterase (Figures 3B-3E) were also demonstrated while the alkaline phosphatase activity was feeble while lipase activity was absent.

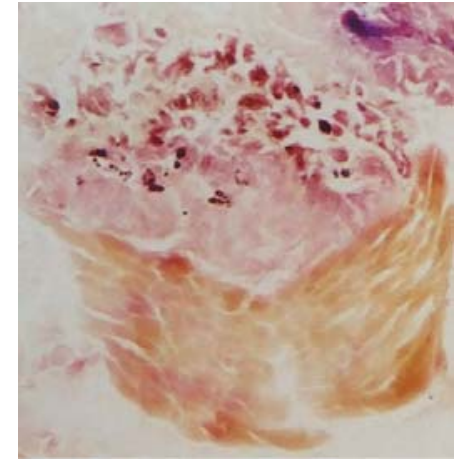

(A)

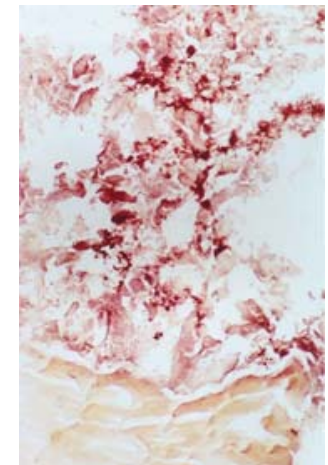

(B)

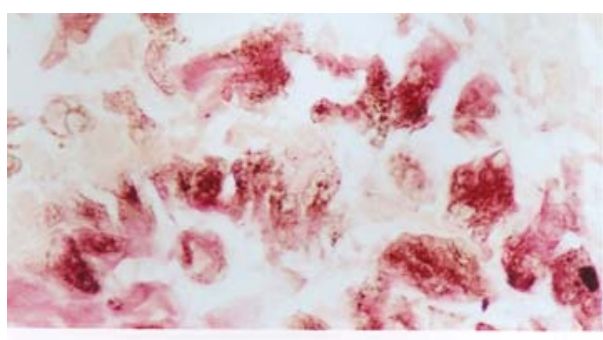

(C)

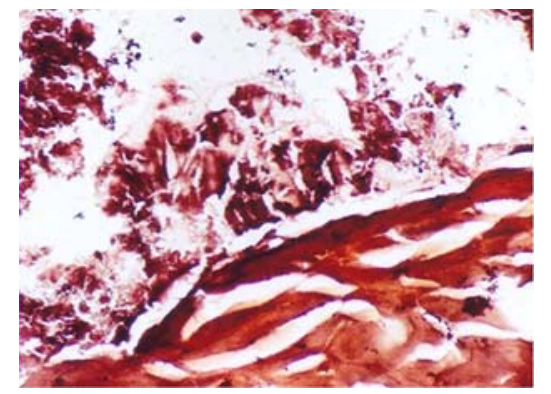

(D)

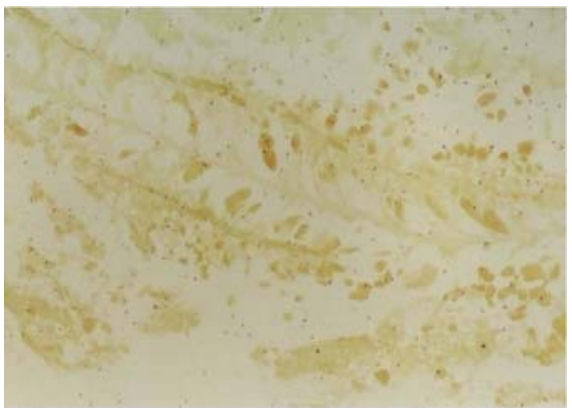

(E)

Figure 3. Cross-section of $A$. crassicauda venom glands presenting: (A) aminopeptidase activity; (B) acid phosphatase activity; (C) mitochondrial ATPase activity; (D) non-specific esterase activity; (E) cholinesterase activity.

\section{DISCUSSION}

A tentative interpretation of mucosubstance type secreted by the $A$. crassicauda venom gland could be made depending on both the present results and classification basis of mucosubstances, as proposed by various histochemists $(9,18,22,32)$. Thus, in the present study the venom-producing cells of $A$. crassicauda were found to be PAS-positive and diastase-resistant, which indicates that this scorpion species 
B. M. Jarrar and M. A. Al-Rowaily HISTOLOGY AND HISTOCHEMISTRY OF THE VENOM APPARATUS OF THE BLACK SCORPION Androctonus crassicauda (OLIVIER, 1807) (SCORPIONES: BUTHIDAE). J. Venom. Anim. Toxins incl. Trop. Dis., 2008, 14, 3, p. 523

venom contains neutral mucosubstances and are devoid of glycogen. On the other hand, its glands were positive by the specific techniques of alcian blue and aldehyde fuchsin, and therefore considered organs that secrete acidic mucosubstances. According to Pearse's interpretation (32), A. crassicauda venom has been shown to contain neutral mucosubstances, sialidase-labile sialomucins and hyaluronidaseresistant sulphomucins. Neutral mucosubstances have been found in the venom of some other scorpion species and are reported to be abundant in the most dangerous ones $(19,20,34)$. The nature of neutral mucosubstances, which are polymers of glucosamine, may indicate a possible role in osmoregulation and in the transfer of venom protein fragment's to the victim's tissue. The present investigation's finding that contradicts those from previous studies $(19,27,34)$ is the presence of both sialomucins and sulfomucins in the venom of $A$. crassicauda. In this respect, Leiurus quinquestriatus venom contains sialomucins but no sulfomucins (34), while the venoms of Heterometrus scaber and Pandinus imperator include sulfomucins rather than sialomucins $(19,27)$. Sialomucins and sulfomucins present in the $A$. crassicauda venom, as seen in the present work, may indicate a role in accelerating venom absorption upon injection into the victim.

The histochemical outcomes of the current investigation indicate the presence of cysteine, arginine, tyrosine and tryptophan in A. crassicauda venom. Cysteine may provide sulfhydryl groups that can interact to stabilize the venom fractions, while arginine suggests a basic aspect of protein. It is believed that basic proteins are responsible for venom neurotoxic activities that may block sodium channels of excitable cell membranes $(11,17)$. Tryptophan in Tityus serrulatus venom was found to contribute to the binding of the toxin to victim neuronal membranes (21).

The results of the present research demonstrate that $A$. crassicauda venom possesses considerable activity of phosphatase, aminopeptidase, cholinesterase and non-specific esterase. Alkaline phophatase activity was also revealed in the venoms of Leiurus quinquestriatus, Palamneus gravimanus, Hardrurus arizonesis and Paroroctonus mesaensis $(27,29,30)$, while proteinase activity was recognized in toxins from L. quinquestriatus and Buthus quinquestriatus (26, 34). Aminopeptidase may facilitate distribution of other venom components at the injection site. Phosphatases and esterases in scorpion venom may play a part in the victim's shock through a cardiac reflex while cholinesterases inhibit muscle control by affecting the neuron end-plates, thereby immobilizing small prey (2). The activity of some other 
B. M. Jarrar and M. A. Al-Rowaily HISTOLOGY AND HISTOCHEMISTRY OF THE VENOM APPARATUS OF THE BLACK SCORPION Androctonus crassicauda (OLIVIER, 1807) (SCORPIONES: BUTHIDAE). J. Venom. Anim. Toxins incl. Trop. Dis., 2008, 14, 3, p. 524

enzymes such as hyluronidase and phospholipase was detected from the venom of other scorpion species (33). Hyaluronidase aids in separating acidic mucosubstances of connective tissues, which quickens the venom absorption in the victim while phospholipase decomposes membrane phospholipids of the target cells. However, the real role of these venom enzymes remains unknown and requires more clarification.

Additional histochemical investigations are needed on the venom of scorpions to identify their toxic and non-toxic antigenic components.

\section{REFERENCES}

1 AL-ASMARI AK., AL-SAIF AA. Scorpion sting syndrome in a general hospital in Saudi Arabia. Saudi Med. J., 2004, 25, 64-70.

2 AL-SADOON MK. Scorpions and snake species of Al-Jouf Province. Skaka: AlRahmaniya Establishment, 2004.

3 AL-SADOON MK., AL-FARAJ S. Scorpions of Saudi Arabia. Riyadh: Al-Mehmas Press, 2001.

4 AL-SADOON MK., JARRAR BM. Study of the frequency and incidence of scorpion stings and snakebites in Riyadh city. J. King. Saudi Univ. Sci., 1994, 6, 21766.

5 AL-SADOON MK., JARRAR BM. Epidemiological study of scorpion stings in Saudi Arabia between 1993 and 1997. J. Venom. Anim. Toxins, 2003, 9, 1-8.

6 AMR Z., AL-ORAN R., AMR S. Scorpion stings in Jordan. Ann. Trop. Med. Parasitol., 1994, 88, 99-101.

7 AMR Z., AL-ORAN R., AMR S. Scorpion and scorpion stings in Jordan. Bull. Soc. Pathol. Exot. Filiales, 1988, 81, 369-79.

8 ANNOBIL SH. Scorpion stings in children in the Asir Province of Saudi Arabia. J. Wilderness Med., 1995, 4, 241-51.

9 BANCROFT JD., STEVENS A. Theory and practice of histological techniques. 2.ed. London: Churchill Livingstone, 1986.

10 BRENNAN R., KUMAR E., JAGGARO N. Scorpion stings in the Al-Baha Region. Saudi Med. J., 1989, 10, 25-7.

11 CATTERALL WA. Purification of a toxic protein from scorpion venom which activates the action potential $\mathrm{Na}^{+}$ionphore. J. Biol. Chem., 1976, 251, 5528-36. 
B. M. Jarrar and M. A. Al-Rowaily HISTOLOGY AND HISTOCHEMISTRY OF THE VENOM APPARATUS OF THE BLACK SCORPION Androctonus crassicauda (OLIVIER, 1807) (SCORPIONES: BUTHIDAE). J. Venom. Anim. Toxins incl. Trop. Dis., 2008, 14, 3, p. 525

12 DITTRICH K., POWER AP., SMITH NA. Scorpion sting syndrome - a ten year experience. Ann. Saudi Med., 1995, 15, 148-55.

13 DRURY RA., WALLINGTON B. Carleto's histological techniques. 5.ed. New York: Oxford University Press, 1983.

14 EL-AMIN EO., DIN-KHAN MD. Haematological and biochemical findings in scorpion stung children. Ann. Saudi Med., 1991, 11, 625-7.

15 EL-HENNAWY HK. A catalogue of the scorpions described from the Arab countries (1758-1990). Serket, 1990, 2, 95-153.

16 FATANI AJ. Some pharmacological studies of the cardiovascular and related effects of scorpion envenomation: the setting up as an experimental treatment protocol. 127p. King Saud: King Saud University, 1987. [Masters thesis].

17 FONTECILLA-CAMPS JC., ALMASSY RJ., SUDDATH FL., WATT DD., BUGG $\mathrm{CE}$. Three-dimentional structure of a protein from scorpion venom: a new structural class of neurotoxins. Proc. Natl. Acad. Sci. USA, 1980, 11, 6496-500.

18 GABE M., SAINT-GIRONS H. Donnees histologiques sur les glands salivaires des lepidosauriens. Mem. Mus. Natl. Hist. Nat., 1969, 58, 1-112.

19 GOYFFON M., KOVOOR J. Chactoid venoms. In: BETTINI S. Ed. Arthropod Venoms. Berlin: Springer-Verlag, 1978: 395-417.

20 HASLE SA., PRIDEAUX PL., COCKSON A., ZWICKY KT. Observations on the morphology and histochemistry of the venom glands of scorpion, Urodacus novabollandiae Peters (Scorpionidae). Australian J. Zool., 1980, 28, 185-94.

21 HASSANI O., MANSUELLE P., CESTELE S., BOURDEAUX M., ROCHAT H., SAMPIERI F. Role of lysine and tryptophan residues in the biological activity of toxin VII (Ts Y) from the scorpion Tityus serrulatus. Eur. J. Biochem., 1999, 260, 76-86.

22 KIERNAN JH. Histological and histochemical methods. Theory and practice. 2.ed. Oxford: Pergamon Press, 1989. 433p.

23 LOJDA Z., GOSSRAU R., SCHIEBLER TH. Enzyme histochemistry: a laboratory manual. Berlin: Springer-Verlag, 1979.

24 MAHABA MH., EL-SAYED S. Scorpion sting, is it a health problem in Saudi Arabia? Evaluation and management of 820 cases. Saudi Med. J., 1996, 17, 315-21. 25 MAZURKIEWICZ JE., BERTKE EM. Ultrastructure of the venom gland of the scorpion Centruroides sculpturatus (Ewing). J. Morphol., 1972, 137, 365-84.

26 MOHAMMED AH., KAMEL A., AYOBE MA. Some enzymatic activities of Egyptian snake venoms and scorpion venom. Toxicon, 1969, 7, 185-8. 
B. M. Jarrar and M. A. Al-Rowaily HISTOLOGY AND HISTOCHEMISTRY OF THE VENOM APPARATUS OF THE BLACK SCORPION Androctonus crassicauda (OLIVIER, 1807) (SCORPIONES: BUTHIDAE). J. Venom. Anim. Toxins incl. Trop. Dis., 2008, 14, 3, p. 526

27 NAIR BR., KURUP PA. Glycosaminoglycans in the venom of the South Indian scorpion, Heterometrus scaber. Indian J. Biochem. Biophys., 1973, 10, 133-4.

28 NEALE JR. Scorpion sting syndrome in Eastern Riyadh. Ann. Saudi Med., 1990, $10,383$.

29 NICHOLS OG. The composition, formation and secretion of venom in the scorpion Urodacus novabollandiae. Sydnei: University of Western Australia, 1976. [Doctoral thesis]

30 OZCAN O., ADIGUZEL S., YAKISTRAIN S., FILAZI A. Study of relationship between Androctonus crassicauda (Oliver, 1807; Scorpions, Buthidae) venom toxicity and telson size, weight and strong condition. J. Venom. Anim. Toxins incl. Trop. Dis., 2006, 12, 297-309.

31 PEARSE AGE. Histochemistry. Theorical and applied. 3.ed. London: Churchill Livingstone, 1972. 2v.

32 PEARSE AGE. Histochemistry. Theorical and applied, analytical technology. 4.ed. London: Churchill Livingstone, 1985.

33 PESSINI AC., TAKAO TT., CAVALHEIRO EC., VICHNEWSKI W., SAMPAIO SV., GIGLIO JR., ARANTES EC. A hyaluronidase from Tityus serrulatus scorpion venom: isolation, characterization and inhibition by flavoids. Toxicon, 2001, 39, 1495505.

34 TAIB NT., JARRAR BM. Histological and histochemical characterization of the venom apparatus of Palestine yellow scorpion, Leiurus quinquestriatus Hemprich \& Ehrenberg 1828. Trop. Zool., 1993, 6, 143-52.

35 VACHON M. Arachnids of Saudi Arabia Scorpions. In: WITTMER W., BUTTIKER W. Eds. Fauna of Saudi Arabia. Basle: Ciba Geigy, 1979: 30-65. 